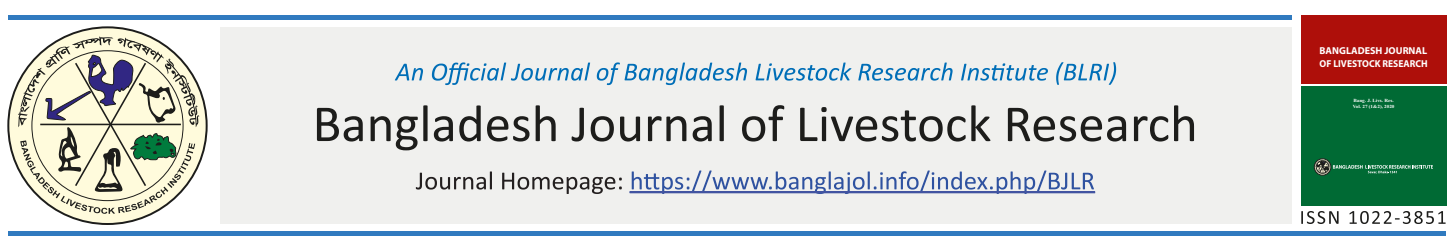

\title{
Effect of feeding high yielding fodders on growth performance of growing Hilly Brown Bengal goat
}

\author{
M. M. Rahman ${ }^{1, *}$, N. R. Sarker ${ }^{2}$ and M. A. Alam ${ }^{3}$ \\ ${ }^{1}$ Biotechnology Division, Bangladesh Livestock Research Institute, Savar, Dhaka, Bangladesh. \\ ${ }^{2}$ Bangladesh Livestock Research Institute, Savar, Dhaka, Bangladesh. \\ ${ }^{3}$ System Research Division, Bangladesh Livestock Research Institute Regional Station, \\ Naikhongchari, Bandarban, Bangladesh.
}

\begin{abstract}
This study was carried out to evaluate the feeding effect of high yielding fodders (HYF) on feed intake and growth performance of growing Hilly Brown Bengal (HBB) goat. For this purpose, a feeding trail was conducted with 16 growing HBB kids (4 to 5 months) by dividing equally in four groups having four replicates for a period of 75 days. The goats in group $\mathrm{T}_{0}$ (control) received natural grass along with $101.30 \mathrm{~g}$ concentrates and adlibitum cowpea hay, whereas in group $\mathrm{T}_{1}, \mathrm{~T}_{2}$ and $\mathrm{T}_{3}$, only natural grass was replaced by BLRI Napier 3, BLRI Napier 4 and Ruzi fodder, respectively. Total dry matter intake (DMI), roughages DMI, crude protein intake (CP), body weight gain $(\mathrm{kg})$, average daily gain $(\mathrm{g})$ and forth night body weight gain (g/day) were studied. Results revealed that, DMI $\left(288.39,285.71,293.48\right.$ and 301.35 g/day in group $\mathrm{T}_{0}, \mathrm{~T}_{1}$, $\mathrm{T}_{2}$ and $\mathrm{T}_{3}$, respectively), body weight gain $\left(3.60,3.74,3.73\right.$ and $3.77 \mathrm{~kg}$ in group $\mathrm{T}_{0}, \mathrm{~T}_{1}, \mathrm{~T}_{2}$ and $\mathrm{T}_{3}$, respectively), average daily gain $\left(47.32,49.16,49.12\right.$ and $48.92 \mathrm{~g}$ in group $\mathrm{T}_{0}, \mathrm{~T}_{1}, \mathrm{~T}_{2}$ and $\mathrm{T}_{3}$, respectively) and feed conversion ratio $\left(6.2,5.9,6.0\right.$ and 6.1 in group $\mathrm{T}_{0}, \mathrm{~T}_{1}, \mathrm{~T}_{2}$ and $\mathrm{T}_{3}$, respectively) of HBB kids were not differed significantly $(\mathrm{P}>0.05)$ for all the treatment groups. The DMI from roughages (196.2, 193.5, 201.3 and $209.2 \mathrm{~g} /$ day in group $\mathrm{T}_{0}, \mathrm{~T}_{1}, \mathrm{~T}_{2}$ and $\mathrm{T}_{3}$, respectively) and $\mathrm{CP}$ intake $\left(38.7,42.1,48.3\right.$ and $38.8 \mathrm{~g} /$ day in group $\mathrm{T}_{0}, \mathrm{~T}_{1}, \mathrm{~T}_{2}$ and $\mathrm{T}_{3}$, respectively) were significantly varied $(\mathrm{P}<0.05)$, while highest $\mathrm{CP}$ intake was found in the treatment group $\mathrm{T}_{2}$. Forthnight body weight (g/day) was not significantly $(\mathrm{P}>0.05)$ gained with feeding of HYF for all the treatment groups. From this study, it can be concluded that, growing HBB kids could equally be supplied with either BLRI Napier 3 or BLRI Napier 4 or Ruzi fodder in addition to ad libitum cowpea hay for better voluntary feed intake and growth.
\end{abstract}

Key words: Hilly Brown Bengal goat, Growth performance, High yielding fodder, Cowpea hay, Feeding effect.

Bang. J. Livs. Res. Vol. 27 (1\&2), 2020: P. 73-81. $\quad$ https://doi.org/10.3329/bjlr.v27i1.55171

\section{Introduction}

Bangladesh, a tropical agro-based country, has the third largest concentrations of goat genotypes, with a population of about 26.43

*Corresponding author: mukul.blri7@gmail.com 
million, which representing almost 47.26 and $6.41 \%$ of total ruminant and livestock population, respectively (Economic review, Department of livestock Services, DLS, 2018). According to the technical Bulletin of Food and Agriculture Organization (FAO) 2017, the Black Bengal Goat (BBG) genotypes comprises more than $90 \%$ of the total goat population, having variety of coat color, e.g. black, black and white, brown, brown and white and white coat color and majority of these goats possess black coat color (69\%) with only 5-7\% brown (Habib et al., 2019; Bhuyain, 2013; Chowdhury et al., 2002). Hilly Brown Bengal (HBB) goat, a coat color variant of $\mathrm{BBG}$, is available at the hilly districts of Bangladesh (Talukdar et al., 2016). They are reputed to be very hardy and capable of thriving in any adverse environmental condition. They are nature browsing goat and allowed to grassing field and can mounting in the hills. This kind of goats are dwarf type breed and known to be famous for its high adaptability, fertility, prolificacy, delicious meat and superior quality skin. Having these phenomenon and are available in hilly parts of Bangladesh they are known as HBB goat. There are a very few work on HBB goat genotypes yet and their systematic information on genetic and phenotypic characteristics is very limited. Some research suggested that they are being reared primarily for meat production, so, body weight and growth rate are considered as the most important factors. (Talukdar et al., 2010).

Again, the majorities of the tribal people, who live in the hilly forests with primitive ways of life, practiced traditional integrated farming system including crop production under shifting cultivation together with homestead garden, livestock, horticulture and forest trees (Alam et al., 1993).
Introduction of livestock especially such kinds of goats may play a vital role in the integrated agro forestry system especially in the hilly districts. HBB goats are nature browsing animal, allowed to grassing field with no supplementation and mounting the hills in most of their grassing times, resulting their exploitation in performances with the reduction of their in-situ and ex-situ population. However, this goat no doubt a promising treasure of hilly districts in Bangladesh is now considered a vulnerable breed types, as this resource are going to be exposed with continuous scarcity of feed, which is the most important and crucial problem in hilly areas. Thought the fodder production practices are not well established and accepted in that region, hence most of the high yielding fodder (HYF) varieties remains unexploited yet. However, pasture land of the hilly areas are gradually decreased due to housing, rubber gardening, horticultural activities including other agricultural task which are the most important and crucial problem in hilly areas for the production of HBB goat. So it is necessary to use limited land for the production of higher biomass of fodder using HYF verities. Moreover, the performances of $\mathrm{HBB}$ goat have not yet been studied with HYF with grade level of concentrate feed so far in these hill tract areas (Talukder et al., 2016). On the other hand, the productive performances of HYF verities and the biomass yield of theses fodders have not yet been documented in the hilly areas. Therefore, the present study was undertaken to investigate the feeding effect of high yielding fodder varieties on the feed intake and growth performance of growing HBB goats in Bangladesh Livestock Research Institute (BLRI) Regional station, Naikhongchari, Bandarban. 


\section{Materials and Methods}

\section{Site of experiment}

This study was carried out in Bangladesh Livestock Research Institute (BLRI), Regional Station Research Farm, Naikhongchari, Bandarban.

\section{Animals and feeding management}

Sixteen growing HBB kids aged about 4 to 5 months with average initial live weight of $5.44 \pm 0.18 \mathrm{~kg}$, were used for a 75 days feeding trial. Goats were randomly assigned to four dietary treatments in a completely pen $(90 \times 85 \times 75 \mathrm{~cm}$. dimension) on a slatted floor raised above the ground with sufficient space for relaxation. Goats were allowed for free movement in the floor daily from 7.00 to 9.00 am and fed with $50 \%$ of the basal concentrate mixture at 9.30 am and the remaining portion was supplied at 4.00 $\mathrm{pm}$. The ad libitum roughage diets (natural grass, fodder and cowpea hay) were fed twice daily after each concentrated feeding. The feed was offered individually and fresh drinking water was available at all times. The ingredient composition of the concentrate mixture contained wheat bran,

Table 1. Experimental design and feeding regime

\begin{tabular}{lcccc}
\hline \multicolumn{1}{c}{ Items } & \multicolumn{4}{c}{ Dietary treatments } \\
\hline Group & $\mathrm{T}_{0}$ & $\mathrm{~T}_{1}$ & $\mathrm{~T}_{2}$ & $\mathrm{~T}_{3}$ \\
Replication & 4 & 4 & 4 & 4 \\
Body Wt. & 5.45 & 5.44 & 5.66 & 5.53 \\
Dietary feeding & Natural grass + & BLRI Napier-3 + & BLRI Napier-4 + & Ruzi + \\
& Cowpea hay & Cowpea hay & Cowpea hay & Cowpea hay \\
Concentrate feed & Basal conc. & Basal conc. & Basal conc. & Basal conc. \\
\hline
\end{tabular}

randomized design (CRD) with four goats in each treatment. The treatment groups of animal was as follows; T0 (Natural grazing + Ad libitum cowpea hay + $101.3 \mathrm{~g}$ concentrate supplementation), T1 (BLRI Napier-3 + Ad libitum cowpea hay + 101.3 g concentrate supplementation), T2 (BLRI Napier-4 + Ad libitum cowpea hay + $101.3 \mathrm{~g}$ concentrate supplementation) and T3 (Ruzi + Ad libitum cowpea hay + $101.3 \mathrm{~g}$ concentrate supplementation) with no grazing. The layout of the experiment followed in the present study is shown in the Table 1.

\section{Housing and feeding management}

The animals were housed together in individual khesari bran, broken maize, soybean meal, DCP, salt and Vit-Min premix at a value of $35,20,20,20,3.5,1.0$ and $0.5 \%$ respectively (Table 2). The ingredient of concentrates mixer were purchased and supplied from BLRI Headquarter and representative samples were collected at the time of their received for proximate analysis following the methods of AOAC (1995). Napier-3, Napier-4, Ruzi and cowpea were cultivated in farm area (BLRI Regional Station Research Farm) for feeding of treatment animals, respectively. The cowpea was dried after harvest and preserved as hay and then supplied to the animals. Leftover of fodders and hays were weighted before offering new feed to the treatment groups. 
Table 2 Composition of experimental concentrates and roughages

\begin{tabular}{|c|c|c|c|c|c|c|}
\hline \multicolumn{5}{|l|}{ Ingredients } & \multicolumn{2}{|c|}{ Percentage (\%) } \\
\hline \multicolumn{5}{|l|}{ Wheat Bran } & \multicolumn{2}{|r|}{35} \\
\hline \multicolumn{5}{|l|}{ Khesari Bran } & \multicolumn{2}{|r|}{20} \\
\hline \multicolumn{5}{|l|}{ Broken maize } & \multicolumn{2}{|r|}{20} \\
\hline \multicolumn{5}{|l|}{ Soybean Meal } & \multicolumn{2}{|r|}{20} \\
\hline \multicolumn{5}{|c|}{ Dicalcium phosphate (DCP) } & \multicolumn{2}{|r|}{3.5} \\
\hline \multicolumn{5}{|l|}{ Salt } & \multicolumn{2}{|r|}{1.0} \\
\hline \multicolumn{5}{|l|}{ Vit -Min premix } & \multicolumn{2}{|r|}{0.5} \\
\hline \multicolumn{5}{|l|}{ Total } & \multicolumn{2}{|c|}{100.00} \\
\hline Chemical composition & Conc. & $\begin{array}{l}\text { Natural } \\
\text { grass }\end{array}$ & $\begin{array}{l}\text { BLRI } \\
\text { Napier-3 } \\
\text { fodder }\end{array}$ & $\begin{array}{l}\text { BLRI } \\
\text { Napier-4 } \\
\text { fodder }\end{array}$ & $\begin{array}{l}\text { Ruzi } \\
\text { fodder }\end{array}$ & Cowpea Hay \\
\hline Dry matter (DM) & 89.45 & 22.00 & 18.21 & 19.08 & 20.90 & 31.80 \\
\hline Crude protein $(\mathrm{CP})$ & 19.4 & 10.90 & 12.98 & 16.94 & 9.30 & 16.00 \\
\hline Ash & 4.45 & 9.70 & 8.43 & 9.18 & 11.34 & 7.70 \\
\hline
\end{tabular}

\section{Health management}

Experimental goats were housed in a clean, well ventilated shed with individual feeding and watering facilities. They were de-wormed orally by given anthelmintics (Fenbendazole $5 \mathrm{mg}$ per $\mathrm{kg} \mathrm{BW}$ ), vaccinated against PPR in the beginning of experiment and allowed to adapt for few days before experimental feeding.

\section{Data collection and analysis}

Feed intake and growth performances were examined for investigation the feeding effect of different HYF. Five (5) days were adaptation periods for concentrate feeding provided to the treatment groups. The individual body weight of the animal was recorded at the beginning of the experiment and subsequently at 15 days interval in the morning hours before feeding and watering. Data collected from the experiment was used to calculate daily body weight gain, average daily weight gain and feed conversion ratio (FCR) for 75 days. The collected data were analyzed statistically by using Compare Means (CM) procedure of One-Way Analysis of variance (ANOVA): Post Hoc Multiple Comparisons of SPSS 11.5 for Windows (SPSS Inc. 2000).

\section{Results and Discussion}

\section{Chemical composition}

The chemical composition of four experimental fodders along with cowpea hay is shown in Table 2. The DM and Ash were found highest for cowpea hay (31.80\%) and Ruzi fodder (11.34\%) and lowest for Napier $3(18.21 \%)$ and cowpea hay $(7.70 \%)$, respectively compared to other fodders and grasses. Among the experimental fodders, highest CP was recorded for Napier 4 (16.94\%) and lowest for Ruzi (9.30\%), respectively. 
From all the experimental groups, DM was obtained in the ranges from 18 to $22 \%$, while $\mathrm{CP}$ ranges from 9 to $17 \%$. The $\mathrm{DM}$ and CP content in Napier fodder were comparable and similar with the earlier observations (Rambau et al., 2016; Gwayumba et al., 2002; Islam et al., 2009). The DM and CP contents of roadside grasses or natural grasses were observed in some previous research (Shahjalal and Topps, 2000; Alam, 1990), ranging from 17 to $20 \%$ and 8 to $11 \%$, respectively, which are in agreement with the values reported in the present findings.

\section{Dry matter (DM) intake}

The comparative voluntary feed intake and growth response of different experimental HYF on growing HBB goat are shown in Table 3. Results revealed that the goats in experimental group of $\mathrm{T}_{1}, \mathrm{~T}_{2}$ and $\mathrm{T}_{3}$ had non-significant effect ( $\mathrm{p}>0.05$ ) on total DM intake (g/day) compared to control $\left(\mathrm{T}_{0}\right)$, while DM intake from roughages (g/day) had observed significant effect $(p<0.05)$ among four treatment groups. The total DM intake was found higher in $\mathrm{T}_{3}$ (301.40) followed by $\mathrm{T}_{2}$ (293.50), $\mathrm{T}_{0}(288.40)$ and $\mathrm{T}_{1}$ (285.70) group whereas, DMI (kg, \% of live weight) was observed as 4.00, 3.96, 4.10 and 4.20 in $\mathrm{T}_{0}, \mathrm{~T}_{1}, \mathrm{~T}_{2}$ and $\mathrm{T}_{3}$ groups, respectively. However, the DMI from all treatments groups represents lower DM intake then other findings (Moniruzzaman et al., 2002; Hossain et al., 2003; Rahman et al., 2015), which might be attributed to the high altitude effect (Kumar et al., 2016) on the feeding of goat in the present study. The greater DMI from roughages $(\mathrm{p}<0.05)$ in treatment group $\mathrm{T}_{3}(209.2 \mathrm{~g} /$ day $)$ resulted higher FCR ( $>0.05)$ values (6.30) compared to other treatment groups. Kabir et al. (2002a) mentioned that DM intake of goat was $3.5 \%$ of live weight. The present finding on DM intake was higher than the above observations. Unlike the present findings, Rahman et al. (2015), reporting significant variation on DM intake with growing goats, with the supplementation of forage based diets. Comparable results for DMI in BB goats fed with road side grasses and Sesbania leaves were studied by Shahjalal and Topps (2000) and observed higher DM intake in Sesbania leaves then road side grasses, which in agreement with the present findings. Since goats are prefer to eat fodders with relatively young and soft leaves, which have highly digestible cellular nutrients such as proteins and carbohydrates (Luginbuhl, 2015). Therefore, in the present study showed that, experimental fodder Ruzi $\left(\mathrm{T}_{3}\right)$ had a higher DM $(20.21 \%)$ that could be attributed to the higher DM intake and DMI from roughages. In the present findings, when natural grass was replaced with BLRI Napier 4 and Ruzi to make experimental diets $\left(\mathrm{T}_{2}\right.$ and $\left.\mathrm{T}_{3}\right)$, their intake by $\mathrm{HBB}$ was increased with the highest DM and CP contents respectively, which were adjusted at a greater nutrition level (Rahman et al., 2015). However, results also showed reduction in DM intake when replacing with BLRI Napier $3\left(\mathrm{~T}_{1}\right)$ in the diets, which might be attributed for its stiffs leaves and complex cell wall structure.

The effect of feeding HYF compared with atural grasses on the $\mathrm{CP}$ intake and growth performance of $\mathrm{HBB}$ weaned goat are presented in the Table 3 . Results in the table depicted that, the total CP intake (g/d) was differed significantly $(\mathrm{p}<0.05)$ among the four treatment groups, where goat in 
Table 3 Nutrient Intake and growth response on growing weaned HBB goat fed different HYF

\begin{tabular}{|c|c|c|c|c|c|}
\hline \multirow{2}{*}{ Parameters } & \multicolumn{4}{|c|}{ Diets $( \pm \mathrm{SD})$} & \multirow[t]{2}{*}{ Sig. } \\
\hline & $\mathrm{T}_{0}$ & $\mathrm{~T}_{1}$ & $\mathrm{~T}_{2}$ & $\mathrm{~T}_{3}$ & \\
\hline Total DMI (g/d) & $288.4 \pm 25.26$ & $285.7 \pm 5.41$ & $293.5 \pm 9.99$ & $301.4 \pm 8.10$ & NS \\
\hline DMI from roughages $(\mathrm{g} / \mathrm{d})$ & $196.2 \pm 12.23$ & $193.5 \pm 17.45$ & $201.3 \pm 3.98$ & $209.2 \pm 2.97$ & $*$ \\
\hline DMI from Concentrates $(\mathrm{g} / \mathrm{d})$ & $92.4 \pm 11.45$ & $91.8 \pm 6.85$ & $86.23 \pm 4.88$ & $92.8 \pm 3.85$ & NS \\
\hline DMI (Kg, \% LW) & $4.0 \pm 0.00$ & $3.96 \pm 0.23$ & $4.1 \pm 0.31$ & $4.2 \pm 0.18$ & NS \\
\hline Total CP Intake (g/d) & $38.7^{b} \pm 2.75$ & $42.1^{\mathrm{b}} \pm 0.69$ & $48.3^{\mathrm{a}} \pm 1.51$ & $38.8^{\mathrm{b}} \pm 0.87$ & $*$ \\
\hline Initial Body Wt. (Kg) & $5.4 \pm 0.65$ & $5.4 \pm 0.42$ & $5.5 \pm 0.63$ & $5.5 \pm 0.40$ & NS \\
\hline Final Body Wt. (Kg) & $9.0 \pm 0.63$ & $9.2 \pm 0.62$ & $9.2 \pm 0.73$ & $9.2 \pm 0.58$ & NS \\
\hline Body Wt. Gain, Kg & $3.6 \pm 0.24$ & $3.7 \pm 0.28$ & $3.7 \pm 0.26$ & $3.7 \pm 0.37$ & NS \\
\hline Avg. Daily Gain (g) & $47.3 \pm 3.14$ & $49.2 \pm 3.66$ & $49.1 \pm 3.37$ & $48.9 \pm 4.89$ & NS \\
\hline FCR (Kg DMI/Kg Body Wt.) & $6.2 \pm 0.75$ & $5.9 \pm 0.41$ & $6.0 \pm 0.25$ & $6.3 \pm 0.45$ & NS \\
\hline
\end{tabular}

NS, Non-significant; *, P $>0.05 ; \mathrm{T}_{0}$, (Natural grazing + Ad libitum cowpea Hay $+101.3 \mathrm{~g}$ concentrate supplementation); $\mathrm{T}_{1}$, (BLRI Napier-3 + Ad libitum cowpea Hay $+101.3 \mathrm{~g}$ concentrate supplementation); $\mathrm{T}_{2}$, (BLRI Napier-4 + Ad libitum cowpea Hay + $101.3 \mathrm{~g}$ concentrate supplementation); $\mathrm{T}_{3}$ (Ruzi fodder + Ad libitum cowpea Hay $+101.3 \mathrm{~g}$ concentrate supplementation).

treatment group $\mathrm{T}_{2}$ had significantly higher $\mathrm{CP}$ intake $(48.307 \mathrm{~g} / \mathrm{d})$ then the group $\mathrm{T}_{1}$ (42.076 g/d), $\mathrm{T}_{3}(38.766 \mathrm{~g} / \mathrm{d})$ and $\mathrm{T} 0(38.681$ g/d). Kabir et al. (2002a) observed CP intake of $76.1 \mathrm{~g} /$ day in goats supplemented with $250 \mathrm{~g}$ concentrate per day, slightly higher than the present findings. Similarly, Salim et al. (2002) observed that CP intake of supplemented group was higher (63.7g/day) than that of the control group (26.5g/day). However, the CP intake from all treatments groups represents lower than other findings (Hossain et al., 2003; Rahman et al., 2015), which might be attributed to the high altitude effect (Kumar et al., 2016) on the feeding of goat in the present findings.

\section{Growth performance}

Average body weight gain (kg), average daily gain (g/day) and FCR (Kg DMI/Kg
Body Wt.) during the experimental period is shown in the Table 3 . Results revealed that the goats in experimental group of $\mathrm{T}_{1}, \mathrm{~T}_{2}$ and $\mathrm{T}_{3}$ had non-significant effect $(\mathrm{p}>0.05)$ on the body weight gain $(\mathrm{kg})$, average daily gain (g/day) and FCR (Kg DMI/Kg Body Wt.) compared to control (T0). The body weight gain and average daily gain was observed in the ranges between 47-49 g/day and 3.6-3.7 $\mathrm{kg}$, respectively, while highest body weight gain was observed in $\mathrm{T}_{1}$ (49.20) followed by $\mathrm{T}_{2}$ (49.10) and $\mathrm{T}_{3}$ (48.90), while lowest gain was observed for the goat fed natural grasses $\left(\mathrm{T}_{0}, 47.30\right)$. Kabir et al. (2002b) found that the growth rate of Black Bengal goats ranged from 37.5 to $40.3 \mathrm{~g} /$ day. The present finding on average daily gain was higher than the above observations. In the present trial, feed conversion Ratio (FCR) was not influenced by feeding of different types of roughages. 


\section{Forth night growth response}

The forth night body weight gain (g/day) for growing weaned HBB goat fed with different HYF for the period of 75 days are presented in Table 4. There had no significant variation among the four treatment groups for the five sections of the forth night body weight gain. The goat in the treatment group $\mathrm{T}_{2}$, gained more body weight for the 1st (0-15 days) and 2 nd (16-30 days) 15 days measurement by 57.67 and $72.75 \mathrm{~g} /$ day, respectively with a highest mean body weight gain (50.67 g/day) compared to other treatment group. Furthermore, in the 3rd (31-45 days), 4th (46-60 days) and 5th (61-75 days) 15 days supplement. Similar result with growing goats found by Tiwari et al., (2012), reporting no significant daily body weight gain by the supplementation of fodder with concentrates. Kabir et al. (2002a) found higher daily growth rate $(62.4 \mathrm{~g} /$ day $)$ in kids that received the high protein diet $(16 \% \mathrm{CP})$ than those fed the low protein diet $(10 \% \mathrm{CP}$; $45.4 \mathrm{~g} /$ day) and the effect continued up to weaning. Tiwari et al. (1983) suggested that better growth rate could be achieved by maintaining kids in smaller groups and under better feeding and management conditions. Sadullah (1991) reported daily gains of $41.0 \mathrm{~g} /$ day from birth to six months of age.

Table 4 Fortnightly body weight gain (g/day) of growing HBB goat

\begin{tabular}{ccccccc}
\hline Days & 0-15 Days & 16-30 days & 31-45 days & 46-60 days & 61-75 days & Mean \\
\hline $\mathrm{T}_{0}$ & 29.00 & 60.17 & 72.75 & 26.73 & 51.60 & 48.05 \\
$\mathrm{~T}_{1}$ & 32.17 & 72.50 & 36.00 & 40.08 & 66.75 & 49.50 \\
$\mathrm{~T}_{2}$ & 57.67 & 72.75 & 31.67 & 37.83 & 53.42 & 50.67 \\
$\mathrm{~T}_{3}$ & 25.93 & 48.42 & 58.48 & 48.42 & 56.40 & 47.53 \\
Level of Sig. & $\mathrm{NS}$ & $\mathrm{NS}$ & $\mathrm{NS}$ & $\mathrm{NS}$ & $\mathrm{NS}$ & $\mathrm{NS}$ \\
\hline
\end{tabular}

NS, Non-significant; $\mathrm{T}_{0}$, (Natural grazing + Ad libitum cowpea Hay $+101.3 \mathrm{~g}$ concentrate supplementation); $\mathrm{T}_{1}$, (BLRI Napier-3 + Ad libitum cowpea Hay + 101.3 g concentrate supplementation); $\mathrm{T}_{2}$, (BLRI Napier-4 + Ad libitum cowpea Hay + 101.3 g concentrate supplementation); $\mathrm{T}_{3}$, (Ruzi fodder + Ad libitum cowpea Hay +101.3 g concentrate supplementation).

measurement, goat in treatment group $\mathrm{T}_{0}, \mathrm{~T}_{3}$ and $\mathrm{T}_{1}$ were showed highest forth night body weight gain by $72.75,48.42$ and 66.75 g/day, respectively.

In this experiment only fodder had no effect on the growth rate because it is well established that before and after weaning kids growth rate remain more or less same or it has no significant effect without concentrate

\section{Conclusion}

It can be concluded that, the feeding of three different fodders (BLRI Napier-3, BLRI Napier-4 and Ruzi) had no significant effect on the intake and growth performances of growing hilly brown Bengal goat compared with the feeding of natural grass. Therefore, all of those experimental high yielding fodders can equally be fed for the hilly brown Bengal goat. 


\section{References}

Alam, M.M., Kabir, M.A. Haque, A.F.M.F., Alam, F.M. and Akteruzzaman, M. 1993. Adaptive performances of six maize (zea maize) composite on hill slopes of the Chittagong hill tracts region. Annals Agr., 3: 1-5.

Alam, M.R. 1990. Effects of Feeding Grasses and Supplements and Drenches on Growth of Goats. In the Development of Feeding Strategies for Improving Ruminant Productivity in Areas of Fluctuating Nutrient Supply Through the Use of Nuclear and Related Techniques. FAO/IAEA Research Coordination Meeting, Khon Kaen, Thiland, October 22-26.

AOAC, 1995. Official Methods of Analysis. 16th edn. Association of Official Analytical Chemist. Washington D.C.

Bhuyain, A.K.F.H. (2013). Farm Animal Genetic Resources in SAARC Countries: Diversity, Conservation and Management; Publisher: SAARC Agriculture Centre (SAC), Dhaka 1215, Bangladesh, p.35.

Choudhury, M.P., Sarker, S.C., Islam, F., Ali, A., Bhuiyan, A.K.F.H., Ibrahim, M.N.M. and Okeyo, A.M. 2012. Morphometry and performance of Black Bengal goats at the rural community level in Bangladesh. Bangladesh J. Anim. Sci., 41(2): 83-89.

DLS, 2018. Economic review, Department of Livestock Services (DLS), Ministry of Fisheries and Livestock, The People's Republic of Bangladesh (www.dls.gov.bd).

FAO, 2017. Food and Agriculture Organization of the United Nations. Production Year Book, Rome, Italy, 67.
Gwayumba, W., Christensen, D.A., McKinnon, J.J and Yu, P. 2002. Dry Matter Intake, Digestibility and Milk Yield by Friesian Cows Fed Two Napier Grass Varieties. Asian-Australasian J. Anim. Sci., 15 (4): 516-521.

Habib, M.A., Akhtar, A., Bhuiyan, A.F.M.F. and Afroz, M.F. 2019. Genetic Expression of Different Coat Colour Variants of Black Bengal Goat (BBG) in Bangladesh. Current Journal of Appl. Sci. Tec. 35(2): 1-7.

Hossain, S.M.J. 2003. Study on performance and milk production performance of Black Bengal goat under semi-intensive management. M. S. Thesis, Department of Animal Science, Bangladesh Agricultural University, Mymensingh, pp. 21-40.

Islam, M.R., Amin, M.R., Kabir, A.K.M.A. and Ahmed, M.U. 2009. Comparative study between semi-intensive and scavenging production system on the performances of Black Bengal goat. J. Bang. Agri. Uni., 7(1): 79-86.

Kabir, F., Sahjalal, M., Chowdhury, S.A., Alam, J. and Islam, M.R. 2002b. Effect of protein supplementation to grazing on growth and reproductive performance in female goats and sheep. Pak. J. Biol. Sci., 5:719-721.

Kabir, F., Shahjalal, M., Miah, G., Uddin, M.J. and Rahman, M.Z. 2002a. Effect of concentrate supplementation to grazing on growth and reproductive performance in female goat and sheep. Journal of Biological Science, 2: 333-335. 
Kumar, P., Bharti,V.K., Jadhav, S.E., Charan, G., Gogoi, D. and Srivastava, R.B. 2016. Evaluation of water and feed intake and growth performance of goat (Capra hircus) at high altitude. Animal Nutrition and Feed Technology. 16 (3): 521-6.

Luginbuhl, J.M. 2015. Nutritional feeding management of meat goats. Raleigh, NC, USA: NC State Extension Publications.

Moniruzzaman, M., Hashem, M.A., Akhter, S. and Hossain, M.M. 2002. Effect of Feeding Systems on Feed Intake, Eating Behavior, Growth, Reproductive Performance and Parasitic Infestation of Black Bengal Goat. Asian-Australasian Journal of Animal Science, 15(10): 1453-1457.

Rahman, M.Z., Akbar, M.A., Hossain, M.A. and Ali, M.Y. 2015. Effect of tree forage supplementation on growth performance of goats. Asian Journal of Medical and Biological Research, 1 (2): 209-215.

Rahman, M.M., Abdullah, R.B., Wan Khadijah, W.E., Nakagawa, T., Akashi, R. 2015. Feed intake and growth performance of goats fed with Napier grass and oil palm frond supplemented with soya waste. Journal of Applied Animal Research, 43: 256-60

Rambau, M.D., Fushai F. and Baloyi, J.J. 2016. Productivity, chemical composition and ruminal degradability of irrigated Napier grass leaves harvested at three stages of maturity. South African Journal of Animal Science, 46 (4): 398-408.
Sadullah, M. 1991. Availability and utilization of feed resources for ruminant production in Bangladesh.

Paper Presented on Training Courses on Feed Information System, Bangladesh Agricultural Research Council, Dhaka, Bangladesh.

Shahjalal, M. and Topps, J.H. 2000. Feeding Sesbania Leaves as a Sole Feed on Growth and Nutrient Utilization in Goats. Asian-Australasian J. Ani. Sci., 13(4): 487-489).

SPSS. Windows for version, 11.5. (Microsoft Crop. 1998). Trends SPSS Inc., 2000. Michigan Avenue, Chicago, IL. 19-182.

Talukder, M.A.I., Rahman, M.M., Alam, M.A. and Hemayet, M.A. 2016. Productive and reproductive performances of Brown Bengal goat (Hilly goat) at research farm level. Asian J. Med Bio. Res., 2 (3): 477-482.

Talukder, M.A.I. 2010. Community based hilly goat development at Naikhongchari. Annual Research Review workshop, Bangladesh Livestock Research Institute, Savar, Dhaka-1341. Pp-45-46.

Tiwari, M. R., Shrestha, B. K., Mandal, P. and Panday, L. N 2012. Growth Performance of Khari Goats on Supplementation of Urea Molasses Mineral Block (UMMB) in Fodder Based Diets. Nepal J. Sci. Tech. 13 (2):29-32.

Tiwari, S.B., Saini, A.L. and Bhat, P.N. 1983: Management of Barbari goats. Annual Report, Central Institute for Research on Goats, Makhdoom, Mathura, India, pp. 72-75. 